\title{
EKSISTENSI PAJAK DAERAH SEBAGAI WUJUD PELAKSANAAN OTONOMI DAERAH DALAM KERANGKA GOOD FINANCIAL GOVERNANCE
}

\author{
Galih Arya Prathama \\ theboxerfb20@gmail.com \\ Universitas Airlangga
}

\begin{abstract}
The increase of regional capacity in managing the needs of Regional Development accompanied by the Delegation of Authority from Central Government to Regional Government, has implications in increasing the need for Development Funds, while the Regions can't continue to rely on the fulfillment of these needs to the Central Government. In response to this, in implementing Autonomy, the Regions are given additional Authority of Financial Management. Such authority, creates demands for the Regions to be creative and focused in achieving the Government Goals that have been established.,As an effort to execute duties and functions of Regional Government in the form of Regional Financial Management, then a region must be able to recognize the potential and explore all the resources it has. Local Government is expected to dig deeper related to the potential derived from its own financial resources, especially in order to meet the needs of government financing and development in the region, one of them through Local Own Revenue as one of the main sources of Regional Financial Reception. Independence of Local Own Revenue for a Regional Government, giving positive support to the ability of the region in meeting the needs to build the region. Thus, the greater source of income derived from the potential owned by a region, the more freely the area can accommodate the needs of community without the interest of Central Government which is not in accordance with the needs of people in the region.
\end{abstract}

Keywords: Regional Autonomy; Development Fund; Authority; Local Own Revenue.

\begin{abstract}
Abstrak
Peningkatan Kapasitas Daerah dalam mengelola kebutuhan Pembangunan Daerah yang disertai dengan Pelimpahan Kewenangan yang berasal dari Pemerintah Pusat kepada Pemerintah Daerah, menimbulkan implikasi berupa peningkatan kebutuhan akan Dana Pembangunan, sedangkan Daerah tidak dapat terus menggantungkan pemenuhan kebutuhan tersebut kepada Pemerintah Pusat. Menyikapi hal tersebut, dalam melaksanakan Otonomi, Daerah diberi tambahan Kewenangan pengelolaan Keuangan. Kewenangan tersebut, menciptakan tuntutan kepada Daerah untuk menjadi kreatif dan fokus dalam mencapai Sasaran Pemerintahan yang telah ditetapkan. Sebagai upaya pelaksanaan tugas dan fungsi Pemerintahan Daerah dalam bentuk pelaksanaan Pengelolaan Keuangan Daerah, maka suatu daerah harus dapat mengenali potensi dan menggali seluruh sumber daya yang dimilliki. Pemerintah Daerah diharapkan mampu menggali lebih dalam terkait potensi yang berasal dari sumber-sumber keuangannya sendiri, khususnya dalam rangka memenuhi kebutuhan pembiayaan pemerintahan dan pembangunan di daerahnya, salah satunya melalui Pendapatan Asli Daerah (PAD) sebagai salah satu sumber Penerimaan Keuangan Daerah yang utama. Kemandirian Pendapatan Asli Daerah (PAD) bagi suatu Pemerintahan Daerah, memberikan dukungan secara positif terhadap kemampuan daerah dalam memenuhi kebutuhan untuk membangun daerah. Sehingga, semakin besar sumber Pendapatan yang berasal dari Potensi yang dimiliki suatu daerah, maka semakin leluasa Daerah tersebut dapat mengakomodasikan kebutuhan masyarakatnya tanpa muatan kepentingan Pemerintah Pusat yang tidak sesuai dengan kebutuhan masyarakat di daerah.

Kata Kunci: Otonomi Daerah; Dana Pembangunan; Kewenangan; Pendapatan Asli Daerah (PAD).
\end{abstract}




\section{Pendahuluan}

Pembangunan Daerah merupakan suatu upaya sistematis yang dilaksanakan oleh Pemerintahan Daerah, dengan mengikutsertakan Sektor Swasta dan Kelompok Masyarakat, melalui upaya pemanfaatan seluruh Sumber Daya yang tersedia di daerah. Hal tersebut dilakukan untuk mendukung peningkatan pertumbuhan ekonomi dan kesejahteraan sosial demi peningkatan Kehidupan Masyarakat Daerah.

Dalam rangka mendukung proses Pembangunan Daerah tersebut, Pemerintah Pusat melalui Undang-Undang Nomor 23 Tahun 2014 Tentang Pemerintahan Daerah (selanjutnya disebut dengan UU No. 23/2014) telah menetapkan prinsip dasar Pemerintahan Daerah dengan menggunakan Sistem Otonomi Daerah, melalui pemberlakuan Asas Desentralisasi (daerah otonom) dan Asas Dekonsentrasi (wilayah administratif) sebagai dasar pelaksanaan sistem Otonomi Daerah tersebut, ${ }^{1}$ sehingga Daerah memiliki kewenangan yang lebih besar untuk melaksanakan pembangunannya berdasarkan lokalitas yang lebih tinggi dalam upaya mensejahterakan masyarakat di daerahnya.

Pemberlakuan sistem Otonomi Daerah tersebut telah berlaku di Indonesia melalui Undang-Undang Nomor 22 Tahun 1999 tentang Pemerintahan Daerah. Pada tahun 2004, Undang-Undang Nomor 22 Tahun 1999 mengenai Pemerintahan Daerah dirubah dan disempurnakan dengan Undang-Undang Nomor 32 Tahun 2004 tentang Pemerintah Daerah. Dalam perkembangan terakhir, untuk merespon tuntutan perkembangan keadaan dan peningkatan implementasi Otonomi Daerah, Undang-Undang tersebut diganti dengan UU No. 23/2014 Tentang Pemerintahan Daerah.

Dalam rangka menjalankan fungsi dan kewenangan Pemerintahan Daerah dalam bentuk pelaksanaan Pengelolaan Keuangan Daerah, maka suatu daerah harus dapat mengenali Potensi dan mengidentifikasi sumber-sumber daya yang dimilliki. Pemerintah Daerah diharapkan lebih mampu menggali potensi yang berasal dari

${ }^{1}$ Soekarwo, Berbagai Permasalahan Keuangan Daerah, (Airlangga University Press 2003).[87]. 
sumber-sumber Keuangannya sendiri, khususnya untuk memenuhi kebutuhan pembiayaan pemerintahan dan pembangunan di daerahnya, yang salah satunya melalui Pendapatan Asli Daerah (PAD) sebagai sumber Penerimaan Keuangan Daerah.

Kemandirian Pendapatan Asli Daerah (PAD) bagi suatu Pemerintahan Daerah, akan memberikan dukungan secara positif terhadap kemandirian Daerah dalam memenuhi kebutuhan yang diperlukan untuk membangun daerah melalui pengalokasian anggaran ke dalam APBD. Sehingga, semakin besar sumber Pendapatan yang berasal dari Potensi yang dimiliki suatu daerah, maka semakin leluasa Daerah tersebut untuk mengakomodasikan kebutuhan masyarakatnya tanpa muatan kepentingan Pemerintah Pusat yang tidak sesuai dengan kebutuhan masyarakat di daerah. Dengan demikian Pemerintah Daerah akan lebih mudah memberikan Pertanggungjawaban pelaksanaan Pemerintahan kepada masyarakat atau DPRD . Maka dalam rangka meningkatkan Pendapatan Asli Daerah, Pemerintah Daerah harus berusaha mencari sumber-sumber keuangan daerah yang potensial, yang sebagian besar melalui Pajak Daerah dan Retribusi Daerah.

Berdasarkan latar belakang tersebut, maka dalam kaitannya dengan eksistensi pajak daerah sebagai bagian dari sistem desentralisasi fiskal, terdapat 2 (dua) isu yang menarik untuk dibahas dengan cermat, yaitu fungsi pajak daerah sebagai realisasi desentralisasi perpajakan dan sistem pemungutan pajak daerah di Indonesia.

\section{Pajak Daerah sebagai Bagian dari Sistem Desentralisasi Fiskal}

Dalam Pasal 1 ayat 1 Undang-Undang Dasar 1945 disebutkan bahwa negara Indonesia adalah negara kesatuan. Konsekuensi dari bentuk negara tersebut, dalam Pasal 18 ayat 1 Undang-Undang Dasar 1945 disebutkan bahwa "Negara Kesatuan Republik Indonesia dibagi atas daerah-daerah provinsi dan daerah provinsi itu dibagi atas kabupaten dan kota, yang tiap-tiap provinsi, kabupaten,dan kota itu mempunyai pemerintahan daerah, yang diatur dengan undang-undang." Artinya, keberadaan pemerintahan daerah diakui sebagai bagian dari penyelenggaraan negara.

Kemudian pada alinea keempat Pembukaan Undang-Undang Dasar 1945 dengan jelas dinyatakan, bahwa negara ini dibentuk dengan tujuan 
untuk meningkatkan kesejahteraan rakyat. Hal tersebut juga menjadi tujuan dibentuknya Pemerintahan daerah dalam hal percepatan terwujudnya kesejahteraan masyarakat melalui peningkatan, pelayanan, pemberdayaan, dan peran serta masyarakat, serta peningkatan daya saing daerah dengan tetap memperhatikan prinsip demokrasi, pemerataan, keadilan, keistimewaan dan kekhususan suatu daerah dalam sistem Negara Kesatuan Republik Indonesia. Upaya peningkatan kesejahteraan rakyat tersebut dalam penyelenggaraan pemerintahan daerah, wajib menggunakan prinsip efisiensi dan efektivitas dengan mengikutsertakan aspek-aspek hubungan antar susunan pemerintahan dan antar pemerintahan daerah, potensi dan keanekaragaman daerah, peluang dan tantangan persaingan global.

Untuk mewujudkan tujuan negara tersebut kiranya negara sebagai pemegang mandat dari rakyat, wajib bertanggungjawab dalam melaksanakan pelayanan publik, sebagai usaha pemenuhan terhadap hak-hak dasar rakyat. Dalam hal ini, posisi negara (termasuk pemerintah daerah) merupakan pelayan masyarakat (public service) dari pengguna layanan. Sementara rakyat memiliki hak atas pelayanan publik yang dilaksanakan oleh negara, antara lain hak untuk memperoleh layanan dalam bidang perpajakan, termasuk di dalamnya perlindungan hak-hak sebagai subyek pajak.

Pemungutan pajak merupakan kewenangan negara, sebagaimana diamanahkan oleh konstitusi, pada Pasal 23A Undang-Undang Dasar 1945 yang menyatakan bahwa "Pajak dan pungutan lain yang bersifat memaksa untuk keperluan negara diatur dengan undang-undang”. Kebijakan terkait pemungutan perpajakan adalah instrumen kebijakan fiskal yang ditetapkan oleh pemerintah dalam melaksanakan fungsi alokasi, distribusi, regulasi, dan stabilitasi. Dalam rangka mengefektifkan pemerintah pusat dari beban yang tidak perlu, dan untuk mendorong kemampuan prakarsa, kreativitas dan inovasi pemerintah daerah dan masyarakat daerah dalam mewujudkan kesejahteraan, maka desentralisasi menjadi suatu kebutuhan yang mendesak. Termasuk dalam hal ini adalah penyerahan sebagian kewenangan pemungutan perpajakan dari pemerintah pusat kepada pemerintahan di bawahnya, 
atau yang dikenal dengan desentralisasi perpajakan. Selanjutnya Rochmat Soemitro juga mendefinisikan pajak sebagai berikut:

"Pajak adalah iuran rakyat kepada kas negara berdasarkan undangundang (yang dapat dipaksakan) dengan tidak mendapat jasa imbal (kontraprestasi), yang langsung dapat ditunjukkan dan yang digunakan untuk membayar pengeluaran umum", dengan penjelasan bahwa: "Dapat dipaksakan" artinya : bila utang pajak tidak dibayar, utang itu dapat ditagih dengan mengunakan kekerasan, melalui surat paksa dan sita, dan juga pelaksanaan penyaderaan; terhadap pembayaran pajak, tidak dapat ditunjukkan jasa timbal-balik tertentu, seperti halnya dengan retribusi”. ${ }^{2}$

Sedangkan Soeparman Soemahamidjaja (1964), dalam disertasinya yang berjudul "Pajak Berdasarkan Asas Gotong Royong" menyatakan "Pajak adalah iuran wajib, berupa uang atau barang, yang dipungut oleh penguasa berdasarkan norma-norma hukum, guna menutup biaya produksi barang-barang dan jasa-jasa kolektif dalam mencapai kesejahteraan umum". ${ }^{3}$

Dengan mencatumkan istilah iuran wajib, Soeparman Soemahamidjaja (1964) mengharapkan terpenuhinya ciri, bahwa pajak dipungut dengan bantuan dari dan kerja sama dengan Wajib Pajak, sehingga perlu dihindari penggunaan istilah “paksaan”. Dengan definisi tersebut di atas dan berbagai pendapat para ahli, maka dapat diidentifikasi karakter dari pajak :

a. Pajak merupakan peralihan kekayaan dari orang/badan ke pemerintah;

b. Pajak dipungut berdasarkan/dengan kekuatan undang-undang serta aturan pelaksanaannya, sehingga dapat dipaksakan;

c. Dalam pembayaran pajak tidak dapat ditunjukan adanya kontraprestasi langsung secara individual yang diberikan oleh pemerintah;

d. Pajak dipungut oleh negara baik oleh pemerintah pusat maupun pemerintah daerah;

e. Pajak diperuntukkan bagi pengeluaran-pengeluaran pemerintah, yang bila dari pemasukannya masih terdapat surplus, dipergunakan untuk membiayai investasi publik;

f. Pajak dapat digunakan sebagai alat untuk mencapai tujuan tertentu dari pemerintah;

g. Pajak dapat dipungut secara langsung atau tidak langsung.

\footnotetext{
${ }^{2}$ Rochmat Soemitro, Dasar-Dasar Hukum Pajak dan Pajak Pendapatan, (Eresco 1990).

3 Soeparman Soemahamidjaja, 'Pajak Berdasarkan Asas Gotong - Royong' (Universitas Padjajaran 1964).
} 


\section{Politik Hukum Pengaturan Pajak Daerah di Indonesia}

Sebelum menginjak pada pembahasan lebih jauh mengenai politik hukum pajak daerah, terlebih dahulu akan diuraikan tentang istilah dan pengertian dari politik hukum. Politik hukum (legal policy) sebagai kebijakan negara (public policy) di bidang hukum, harus dipahami sebagai bagian kebijakan sosial yaitu merupakan usaha setiap masyarakat/pemerintah untuk meningkatkan kesejahteraan warganya di setiap aspek kehidupan. Hal tersebut mengandung dua dimensi yang terkait satu dengan yang lain, yakni kebijakan kesejahteraan sosial (social welfare policy) dan kebijakan perlindungan sosial (social defence policy). Dalam pembahasan selanjutnya, politik hukum disebut juga sebagai upaya untuk menentukan suatu pilihan mengenai tujuan dan cara-cara yang hendaknya dipakai atau sebagai kegiatan-kegiatan memilih nilai-nilai dan menerapkan nilai-nilai. ${ }^{4}$

Abdul Hakim Garuda Nusantara, mendefenisikan bahwa pengertian politik hukum juga bervariasi, namun dengan meyakini adanya persamaan substantif antar berbagai pengertian yang ada, studi ini mengambil pengertian bahwa politik hukum adalah legal policy yang akan atau telah dilaksanakan secara nasional oleh pemerintah Indonesia yang meliputi: Pertama, pembangunan hukum yang berintikan pembuatan dan pembaharuan terhadap materi-materi hukum agar dapat sesuai dengan kebutuhan. Kedua, pelaksanaan kebutuhan hukum yang telah ada termasuk penegasan fungsi lembaga dan pembinaan para penegak hukum. ${ }^{5}$

Sebagaimana bunyi Pasal 1 ayat 3 Undang-Undang Dasar 1945 menyatakan bahwa "Negara Indonesia adalah negara hukum”. Prinsip negara hukum sangat terkait dengan asas legalitas, yaitu setiap perbuatan pemerintah sebagai penyelenggara pemerintahan di daerah dan rakyat harus berdasarkan kepada norma hukum yang telah ditentukan. Salah satu asas yang berlaku dalam negara hukum adalah asas

${ }^{4}$ Purnadi Purbacaraka dan Soerjono Soekanto, Sendi-Sendi Ilmu Hukum Dan Tata Hukum (Alumni 1986).[20].

5 ibid.[9]. 
legalitas. Asas legalitas ini mengandung pengertian bahwa semua tindakan negara harus didasarkan dan dibatasi oleh hukum. Negara hukum Indonesia bukanlah negara hukum dalam pengertiannya yang sempit, melainkan negara kemakmuran yang berdasarkan hukum yang dilandasi oleh Pancasila, baik sebagai dasar negara maupun sebagai sumberdari segala sumber hukum, dengan menolak absolutisme dalam segala bentuknya. ${ }^{6}$

Indonesia sebagai negara hukum, diwajibkan untuk mengatur lebih lanjut bidang perpajakan berdasarkan atas hukum, maka segala tindakan termasuk bidang perpajakan harus didasarkan atas aturan hukum yang berlaku. Berdasarkan ketentuan tersebut, pengaturan pajak harus dibuat sesuai proses pembuatan undangundang. Di dalam Pasal 23A Undang-Undang Dasar 1945 secara tegas dinyatakan bahwa "segala pajak dan pungutan lain yang bersifat memaksa untuk keperluan negara berdasarkan undang-undang”. Berdasarkan Pasal tersebut, maka selanjutnya ditetapkan undang-undang yang mengatur tentang pajak daerah.

Dalam sejarahnya, Indonesia memiliki beberapa pengaturan mengenai pajak daerah diantaranya Undang-Undang Nomor 11 Drt. Tahun 1957 tentang Peraturan Umum Pajak, Undang-Undang Nomor 18 Tahun 1997 tentang Pajak Daerah dan Retribusi Daerah, Undang-Undang Nomor 34 Tahun 2000 tentang Pajak Daerah dan Retribusi Daerah, Undang-Undang Nomor 28 Tahun 2009 tentang Pajak dan Retribusi Daerah. Berikut dapat dijelaskan politik hukum dari masing-masing perundangundangan tersebut. Menurut Usman dan Subroto, ${ }^{7}$ Pajak Daerah dapat digolongkan menjadi dua, yaitu pajak-pajak yang telah dari semula menjadi pajak daerah dan pajakpajak Negara yang pemungutannya kemudian diserahkan kepada Pemerintah Daerah.

I. Pajak-Pajak yang dari awalnya merupakan Pajak Daerah

Pajak-pajak yang yang dari semula dipungut oleh Pemerintah Daerah terdiri dari pajak-pajak sebagai berikut: ${ }^{8}$

6 Sjachran Basah, Eksistensi Dan Tolok Ukur Badan Peradilan Administrasi Di Indonesia (Alumni 1985).[147].

${ }^{7}$ Usman dan K. Subroto, Pajak-Pajak Indonesia (Yayasan Bina Pajak 1980).[155-157].

${ }^{8}$ ibid. 
A. Dipungut oleh Pemerintah Provinsi (dulu Dati I):

1. Pajak atas izin menangkap ikan di perairan umum dalam wilayah daerah tersebut. Pajak sekolah yang semata-mata diperuntukkan untuk membiayai pembangunan rumah-rumah sekolah rakyat yang menjadi beban Pemerintah Daerah;

2. Pajak sekolah yang semata-mata diperuntukkan untuk membiayai pembangunan rumah-rumah sekolah rakyat yang menjadi beban Pemerintah Daerah;

3. Opsen atas pokok Pajak Kekayaan (Ordonansi Pajak Kekayaan 1932);

4. Opsen atas pajak (cukai) penjualan bensin (Pasal 13 UU No.11 Drt Tahun 1957).

B. Dipungut oleh Pemerintah Daerah Kabupaten/Kota (dulu Dati II):

1. Pajak atas pertunjukan dan keramaian umum;

2. Pajak atas reklame sepanjang tidak dimuat dalam majalah atau warta harian;

3. Pajak anjing;

4. Pajak atas izin penjualan atau pembuatan petasan dan kembang api;

5. Pajak atas penjualan minuman yang mengandung alkohol;

6. Pajak atas kendaraan tak bermotor;

7. Pajak atas izin mengadakan perjudian;

8. Pajak atas tanda kemewahan mengenai luas dan hiasan kuburan;

9. Pajak karena berdiam diri di suatu daerah lebih dari 120 hari dalam satu tahun pajak kecuali untuk perawatan sakit, menjalankan tugas negara;

10. Pajak atas milik berupa bangunan serta halamannya yang berbatas dengan jalan umum di darat atau di air atau yang terletak di sekitarnya dan juga atas milik berupa tanah kosong yang berbatasan atau yang mempunyai jalan keluar pada jalan-jalan tersebut;

11. Pajak atas milik berupa bangunan serta keturutannya atau tanah kosong yang terletak dalam bagian tertentu dari daerah;

12. Pajak atas milik berupa bangunan serta halamannya yang berbatasan dengan jalan umum di darat atau di air atau dengan lapangan, atau pajak atas tanah yang menurut rencana bangunan daerah yang telah disahkan, akan dipergunakan sebagai tanah bangunan dan terletak dalam lingkungan yang ditentukan oleh DPRD;

13. Pajak sekolah yang semata-mata diperuntukkan membiayai pembangunan rumah sekolah rendah untuk pelajaran umum dan pembelian perlengkapan pertama;

14. Opsen atas pokok Pajak Daerah tingkat atasan sepanjang pemungutan opsen itu diberikan dalam peraturan pajak tingkat itu.

II. Pajak-Pajak Negara yang Diserahkan kepada Daerah

Untuk memberikan otonomi dalam bidang keuangan yang lebih luas kepada setiap Pemerintah Daerah, maka beberapa pajak yang pemungutannya berada pada 
Pemerintah Pusat (Pajak Negara) kemudian diserahkan pemungutannya kepada Pemerintah Daerah untuk menjadi Pajak Daerah. Penyerahan pajak-pajak Negara menjadi Pajak Daerah diatur berdasarkan Undang-Undang Nomor 12 Tahun 1956 tentang Perimbangan Keuangan antara Pusat dan Daerah (UU No. 12/1956) yang berhak mengurus rumah tangganya sendiri jo Peraturan Pemerintah Nomor 3 Tahun 1957 tentang Penyerahan Pajak Negara Kepada Daerah (PP No. 3/1957), serta berdasarkan Undang-Undang Nomor 10 Tahun 1968 tentang Penyerahan Pajak-Pajak Negara (UU No. 10/1968). Pajak-pajak tersebut meliputi:

A. Penyerahan kepada daerah provinsi:

1. Pajak Rumah Tangga (Ordonansi Pajak Rumah Tangga Tahun 1968);

2. Pajak Kendaraan Bermotor (Ordonansi Pajak Kendaraan Bermotor 1934);

3. Pajak Verponding (Ordonansi Verponding 1928);

4. Bea Balik Nama Kendaraan Bermotor.

B. Penyerahan kepada Daerah Kabupaten/Kota:

1. Pajak Jalan (Ordonansi Pajak Jalan 1942);

2. Pajak Kopra - untuk Indonesia kawasan timur;

3. Pajak Potong (Ordonansi Pajak Potong 1936);

4. Pajak Pembangunan I (UU No.14 Tahun 1947);

5. Pajak Verponding Indonesia;

6. Pajak Bangsa Asing (UU No.79 Tahun 1958);

7. Pajak Radio (UU No.12 Tahun 1947).

\section{Teori Pemungutan Pajak dan Teknik Pemungutan Pajak}

Teori development from below berpendapat bahwa orang akan lebih bersedia melakukan pembayaran pajak kepada Pemerintah Daerah daripada Pemerintah Pusat karena mereka dapat secara mudah melihat manfaat langsung dalam pembangunan di daerah mereka. ${ }^{9}$ Berdasarkan teori tersebut, dapat diketahui beberapa permasalahan terkait kemampuan administrasi pajak daerah. Pertama, apakah pemerintah daerah mempunyai cukup kemauan politik untuk mengenakan suatu pajak secara efektif dan adil. Karena pengenaan pajak daerah yang adil membutuhkan suatu kemampuan administrasi data pajak yang akurat.

${ }^{9}$ KJ Davey, Praktek-Praktek Internasional Dan Relevansinya Bagi Dunia Ketiga (UI Press 1988). 
Prakoso ${ }^{10}$ memaparkan terdapat 2 (dua faktor) yang mempengaruhi pelaksanaan tanggungjawab pengenaan dan pemungutan pajak yaitu :

1. Tingkat kemampuan dan ketersediaan tenaga terampil di daerah yang dibutuhkan sebagai tenaga pelaksana administrasi perpajakan di daerah. Tingkat kemampuan dan tersedianya tenaga terampil administratif perpajakan sangat dibutuhkan daerah. Tenaga terampil mungkin terbatas dan sulit bagi pemerintah daerah meskipun ada alternatif seperti menyewa konsultan atau bantuan tenaga dari suatu instansi lain missal, kantor pusat statistik atau jasa asuransi. Instansi ini merupakan tempat tersedianya tenaga ahli yang dapat dimanfaatkan keahliannya dan pengalamannya oleh daerah;

2. Sejauhmana kedekatan pemungut pajak dengan wajib pajak daerah atau desakan politis terhadap keadilan dan ketegasan dalam proses pemungutan pajak tersebut.

Selanjutnya mengenai sistem/teknik pemungutan pajak, menurut Rosdiana terdapat 3 (tiga) teknik pemungutan pajak, yaitu: ${ }^{11}$

1. Official Asesment System

Merupakan sistem pemungutan pajak dimana wewenang untuk menentukan besarnya pajak yang terutang oleh seseorang berada pada emungut atau aparatur pajak.Dalam sistem ini wajib pajak bersifat pasif, menunggu ketetapan dari aparatur pajak, hutang pajak baru timbul bila sudah ada Surat Ketetapan Pajak dari aparatur pajak.

2. Self Assesment System

Sistem pemungutan pajak dimana wewenang untuk menentukan pajak yang terutang oleh wajib pajak berada pada wajib pajak sendiri. Menurut International Tax Glossary, definisi Self Asesment adalah “under selfassessment is meant the sysem which the taxpayer is required not only to declare his basic

\footnotetext{
${ }^{10}$ Damas Dwi Anggoro, Pajak Daerah Dan Retribusi Daerah (UB Press 2017).[ 268].

${ }^{11}$ Haula Rosdiana dan Edi Slamet Irianto, Pengantar Ilmu Pajak, Kebijakan Dan Implementasi Di Indonesia (Rajagrafindo Persada 2012).[106].
} 
of assessment (e.g. taxable income) but also to submit a calculation of the tax due from him and, usually, to accompany his calculation with payment of the amount he regards as due".

Dalam sistem tersebut wajib pajak tidak hanya melaporkan jumlah pajak yang terutang tetapi juga harus aktif menghitung, menetapkan, menyetor sendiri pajak yang terutang.Fiskus berperan untuk mengawasi dan melakukan penelitian terhadap Surat Pemberitahuan (SPT) yang telah diisi dengan lengkap beserta lampirannya, fiskus juga meneliti kebenaran perhitungan.Selain itu, untuk menguji kepatuhan wajib pajak, fiskus dapat melakukan pemeriksaan.

3. Hybrid System / Semi Self Assesment System

Hibridisasi antara Self Assesment dan Official Assesment semakin berkembang pesat sejak diperkenalkannya teknik pemungutan pajak yang popular disebut witholding system. Ide pemungutan pajak dengan witholding, pertama kali diintrodusir di Amerika Serikat pada tahun 1943 dalam rangka mengakselerasi pemungutan pajak selama Perang Dunia II.

\section{Pemungutan Pajak Daerah sebagai Bagian dari Urusan Daerah Otonom}

Pembagian urusan pemerintah pusat dan daerah sebagaimana diatur dalam UU No. 23/2014 pada Pasal 9 disebutkan bahwa :

1. Urusan Pemerintahan terdiri atas urusan pemerintahan absolut, urusan pemerintahan konkuren, dan urusan pemerintahan umum;

2. Urusan pemerintahan absolut sebagaimana dimaksud pada ayat 1 adalah Urusan Pemerintahan yang sepenuhnya menjadi kewenangan Pemerintah Pusat;

3. Urusan pemerintahan konkuren sebagaimana dimaksud pada ayat 1 adalah Urusan Pemerintahan yang dibagi antara Pemerintah Pusat dan Daerah provinsi dan Daerah kabupaten/kota;

4. Urusan pemerintahan konkuren yang diserahkan ke Daerah menjadi dasar pelaksanaan Otonomi Daerah;

5. Urusan pemerintahan umum sebagaimana dimaksud pada ayat 1 adalah Urusan Pemerintahan yang menjadi kewenangan Presiden sebagai kepala pemerintahan.

Pembagian urusan secara rinci antara Pemerintah, Pemerintah Daerah Provinsi dan Pemerintah Daerah Kabupaten/Kota diatur lebih lanjut dalam Lampiran UU No. 23/2014 sebagai bagian yang tidak terpisahkan dari Undang-Undang ini. Ada 
beberapa pengaturan baru dalam Undang-Undang ini terkait pembagian urusan yang sebelumnya diatur dalam Undang-Undang Nomor 32 Tahun 2004 tentang Pemerintahan Daerah juncto Peraturan Pemerintah Nomor 38 Tahun 2007 tentang Pembagian Urusan Pemerintahan antara Pemerintah, Pemerintah Daerah Provinsi dan Pemerintah Daerah Kabupaten/Kota, diantaranya mengenai penyelenggaraan urusan kelautan, energi dan sumber daya mineral yang dibagi antara Pemerintah dan Pemerintah Daerah Provinsi (sebelumnya Pemerintah Daerah Kabupaten/Kota juga berwenang), urusan pendidikan menengah ke atas dialihkan ke Pemerintah Daerah Provinsi (sebelumnya Pemerintah Daerah Kabupaten/Kota), dan lain-lain.

\section{Prosedur Pemungutan Pajak Secara Online}

Untuk mewujudkan kemudahan dan meningkatkan pelayanan kepada Wajib Pajak dalam melakukan pembayaran Pajak Daerah, perlu dilakukan penyempurnaan terhadap penatausahaan dan pertanggungjawan penerimaan Pajak Daerah serta membangun sistem penerimaan Pajak Daerah yang transparan, cepat dan tepat dengan memanfaatkan sarana elektronik.

Secara umum pelayanan Regindent Ranmor, pembayaran PNBP, PKB serta SWDKLLJ pada KB Samsat Jawa Timur, sebelumnya masih menghadapi keluhan dari masyarakat sebagai berikut:

1. Masih melakukan pembayaran secara tunai;

2. Wajib pajak harus menunjukkan dokumen kelengkapan secara fisik;

3. Pelayanan masih harus dilakukan secara tatap muka dengan petugas;

4. Membutuhkan sarana prasarana dengan biaya yang tidak sedikit;

5. Terbatasnya waktu dan tempat pelayanan;

6. Memungkinkannya adanya praktik percaloan.

Oleh karena itu Tim Pembina Samsat Provinsi Jawa Timur melalui KB Samsat melakukan perbaikan dan inovasi layanan publik untuk mengatsi permasalahan tersebut. Tim pembina Samsat Jawa Timur selaku pihak yang bertanggung jawab atas pelaksanaan pelayanan pada KB samsat di Provinsi Jawa Timur untuk memutuskan kebijakan yang tepat dalam meningkatkan tingkat kepedulian dan keterbukaan pemerintah terhadap tuntutan reformasi birokrasi dari masyarakat khususnya Wajib Pajak kendaraan bermotor. 


\section{Kesimpulan}

Keberlakuan dari kebijakan desentralisasi sistem perpajakan yang termasuk dalam kebijakan desentralisasi fiskal telah diterapkan di Indonesia mulai tahun 2001. Sebelumnya, selama 30 tahun lebih Indonesia merupakan salah satu negara yang menerapkan pemerintahan secara sentralistik. Kebijakan desentralisasi tersebut, tertuang dalam bentuk perundang-undangan yang mengatur perimbangan keuangan antara pemerintah pusat dengan pemerintah daerah, dan perundangan tentang pajak dan retribusi daerah.

Sistem pemungutan pajak terdiri dari 3 (tiga) macam yakni Official Assessment System, Self Assessment System, dan With Holding System. Berdasarkan Peraturan Pemerintah Nomor 91 Tahun 2010, sistem pemungutan pajak dibedakan menjadi 2 (dua) yaitu Pajak yang dipungut berdasarkan Penetapan Kepala Daerah (Official Assesment System) untuk jenis Pajak Kendaraan Bermotor (PKB), Bea Balik Nama Kendaraan Bermotor (BBNKB), Pajak Air Permukaan (AP), Pajak Reklame, Pajak Air Tanah dan Pajak Bumi dan Bangunan (PBB) Sektor Perdesaan dan Perkotaan sedangkan Pajak yang dipungut dengan dibayar Sendiri oleh Wajib Pajak (Self Assesment System) untuk jenis Pajak Bahan Bakar Kendaraan Bermotor (BBNKB), Pajak Rokok, Pajak Hotel, Pajak Restoran, Pajak Hiburan, Pajak Penerangan Jalan (PPJ), Pajak Mineral Bukan Logam dan Batuan, Pajak Parkir, Pajak Sarang Burung dan Pajak Bea Perolehan Hak Atas Tanah dan Bangunan (BPHTB). Sedangkan sejak berlakunya Peraturan Pemerintah Nomor 55 Tahun 2016 (yang mencabut Peraturan Pemerintah Nomor 91 Tahun 2010), pengaturan lebih lanjut dari Undang-Undang Nomor 28 Tahun 2009 menjadi semakin rinci dan rigid yaitu mengatur mengenai Ketentuan Umum dan Tata Cara Pemungutan Pajak Daerah. Pengaturan baru dalam Peraturan Pemerintah ini diantaranya mengenai pendaftaran wajib pajak dan masa pajak; penetapan, pembayaran, pelaporan, dan ketetapan pajak; penagihan dan penghapusan piutang pajak; keberatan dan banding; pembukuan dan pemeriksaan; kewajiban pendaftaran obyek pajak. Selain itu diatur juga mengenai jenis pajak yang dapat dibayarkan oleh Pemerintah. Lebih lanjut, berdasarkan Pasal 36 Peraturan Pemerintah Nomor 55 Tahun 2016 disebutkan bahwa peraturan pelaksanaan dari 
Peraturan Pemerintah ini harus ditetapkan paling lama 1 (satu) tahun terhitung sejak Peraturan Pemerintah ini diundangkan. Ada 7 (tujuh) Peraturan yang diamanatkan oleh Peraturan Pemerintah ini, salah satunya mengenai Peraturan Menteri Keuangan tentang Penagihan dan Pemeriksaan Pajak yang belum ada pengaturannya yang terbaru berdasarkan Peraturan Pemerintah Nomor 55 Tahun 2016.

Dalam rangka optimalisasi perolehan pajak daerah sebagai wujud otonomi daerah, perlu komitmen dari Pemerintahan Daerah terhadap pemungutan pajak di daerahnya yang sesuai untuk dijadikan sumber pendapatan agar tercipta efisiensi dan efektivitas dalam pemungutan pajak daerah, dengan cara sebagai berikut : (a) Pemetaan potensi daerah; (b) Evaluasi sistem pemungutan pajak daerah yang sedang berlaku; dan (c) Pembentukan peraturan daerah yang mengatur secara komprehensif tentang pemungutan pajak daerah. Lebih lanjut, dalam tataran peraturan perundangundangan di tingkat nasional, perlu segera dibuat Peraturan Menteri Keuangan tentang Penagihan dan Pemeriksaan Pajak yang lebih komprehensif sesuai amanat Peraturan Pemerintah Nomor 55 Tahun 2016, sehingga dapat mencabut keberlakuan Peraturan Menteri Keuangan Nomor 17/PMK.03/2013, Keputusan Menteri Keuangan Nomor 21/KMK.04/1999, dan Keputusan Menteri Keuangan Nomor 267/KMK.04/1995 yang sudah tidak relevan lagi dengan perkembangan masyarakat.

\section{Daftar Bacaan}

\section{Buku}

Damas Dwi Anggoro, Pajak Daerah Dan Retribusi Daerah (UB Press 2017).

Davey KJ, Praktek-Praktek Internasional Dan Relevansinya Bagi Dunia Ketiga (UI Press 1988).

Haula Rosdiana dan Edi Slamet Irianto, Pengantar Ilmu Pajak, Kebijakan Dan Implementasi Di Indonesia (Rajagrafindo Persada 2012).

Purnadi Purbacaraka dan Soerjono Soekanto, Sendi-Sendi Ilmu Hukum Dan Tata Hukum (Alumni 1986).

Sjachran Basah, Eksistensi Dan Tolok Ukur Badan Peradilan Administrasi Di Indonesia (Alumni 1985). 
Soekarwo, Berbagai Permasalahan Keuangan Daerah, (Airlangga University Press 2003).

\section{Perundangan-undangan}

Undang-Undang Dasar Negara Republik Indonesia 1945.

Undang-Undang Nomor 22 Tahun 1999 Tentang Pemerintahan Daerah.

Undang-Undang Nomor 32 Tahun 2004 tentang Pemerintah Daerah.

Undang-Undang Nomor 12 Tahun 1956 tentang Perimbangan Keuangan antara Pusat dan Daerah.

Undang-Undang Nomor 10 Tahun 1968 tentang Penyerahan Pajak-Pajak Negara

Undang-Undang Nomor 23 Tahun 2014 Tentang Kewenangan Pemungutan Pajak.

Undang-Undang Nomor 28 Tahun 2009 Tentang Pajak Daerah dan Retribusi Daerah.

Peraturan Pemerintah Nomor 55 Tahun 2016 Tentang Teknis Pemungutan Pajak Daerah.

Peraturan Pemerintah Nomor 91 Tahun 2010 Tentang Jenis Pajak Daerah.

HOW TO CITE: Galih Arya Prathama, 'Eksistensi Pajak Daerah Sebagai Wujud Pelaksanaan Otonomi Daerah Dalam Kerangka Good Financial Governance' (2018) Vol. 1 No. 2 Media Iuris. 